\title{
Surfaces
}

\section{Anxieties of Affluence: Movements, Market Sectors, and Lesbian Feminist Generation(s)}

\section{Roundtable 3}

\section{Dana Heller}

Volume 7, 1997

LE FÉMINISME HORS DE LUI-MÊME

FEMINISM BESIDE ITSELF

URI : https://id.erudit.org/iderudit/1064810ar

DOI : https://doi.org/10.7202/1064810ar

Aller au sommaire du numéro

Éditeur(s)

Les Presses de l’Université de Montréal

ISSN

1188-2492 (imprimé)

1200-5320 (numérique)

Découvrir la revue

Citer cet article

Heller, D. (1997). Anxieties of Affluence: Movements, Market Sectors, and

Lesbian Feminist Generation(s): Roundtable 3. Surfaces, 7.

https://doi.org/10.7202/1064810ar d'utilisation que vous pouvez consulter en ligne. 


\section{Anxieties of Affluence: Movements, Market Sectors, and Lesbian Feminist Generation(s) Roundtable 3}

Dana Heller

Old Dominion University

Surfaces Vol. VII.111 (v.1.0A - 27/06/1997) - ISSN:

1188-2492

Copyright for texts published in Surfaces remains the property of authors. However, any further publication should be accompanied by an acknowledgement of Surfaces as the place of initial publication.

Initially, I intended my contribution to this conference to be a rumination on the shift from lesbian feminist to queer politics and the generational anxieties this shift has produced in US feminisms of the 1990s. I set to work in a tenor of gravity and good will, but somehow, somewhere, my fancy turned-as fancies are wont to do-to shopping. How did this happen, you ask? My trouble began when I got sidetracked in an effort to position myself as a generational subject of feminism. To my mind, you see, the term "generation" implies a body of beings who occupy a common step in a line of descent, a body organized by a loose combination of experiences, material practices, and social relationships that animate a generational Geist, a shared sense of history's ineluctable hold on us. But if my engagements with feminist, lesbian, and queer studies have taught me anything over the years it's that no such coherent "bodies" exist, at least not independently of the interests that flesh them out and mobilize them for the construction of a generational identity. Perhaps one 
might argue, as Katie King has argued apropos of feminist origin stories, that feminism's generational anxieties are interested anxieties, all of them.[ 1 ]

For the moment, then, let's consider what angst and what interests generated the shift from lesbian-feminism to queer. According to numerous observers, the lesbian movement away from feminism was decisively marked by sex radicalism.[ $\underline{\mathbf{2}}$ ] In this spirit, Sue-Ellen Case targets 1981-82 as "the great divide," the years that saw the outbreak of the "sex wars," fervid debates motivated not only by s/m lesbian's frustration with anti-pornography feminists but also by an increasingly urgent political crisis stemming from government inattention to HIV and AIDS.[ $\underline{3}$ ] Along with the controversial Scholar and the Feminist IX Conference, "Towards a Politics of Sexuality," held at Barnard College on April 24, 1982, Case commemorates the 1981 release of the film Mommie Dearest, a camp classic and flaming expose on the model Mother whose infamous "attack on any of those hideous wire hangers still found in the closet, likewise produced a routing out of any associations with the iron curtain that continued to inform the political movements concerning alternative sexualities." [ $\underline{4}$ ] By the end of the 1980s, queer "performativity" would effectively represent lesbian-feminism as essentialist and binaryhappy, thus overturning the movement's socialist roots in consonance with the new global capitalism and changing political terminologies that worked to obscure worldwide material conditions.

From lesbian-feminist collectives to queer constituencies, from the Lavender Menace to the Leather Menace, stagings of difference based on genderspecific versus sex-specific analysis, assimilationist versus anti-assimilationist strategies, essentialist versus constructivist approaches have significantly shaped and reshaped feminism's generational imaginary. While the New Left and dialectical materialism produced the theoretical and activist consciousness of a lesbianfeminist generation who came of age in the 60s and 70s, a subsequent generation's political consciousness was produced by the sex wars, poststructuralism, performativism, agitprop, and Queer Nation, which, according to Case, produced a new "queer dyke" who identified more with gay men than lesbians, and whose exit from feminism contributed to the widespread closing down of women-centered bars, bookstores, and cultural centers, many of them collectively owned and operated. Queer Nation's transfiguration into the Queer Shopping Network of New York marked a shift from movement to 
market sector, a politics of celebratory commodification organized around individual market intervention.

Now that "queer" has lost its cutting edge momentum, generational anxieties float freely throughout the divergent discourses of a sexual movement that according to Lauren Berlant and Elizabeth Freeman, poses "as a countercorporation, a business with its own logo, corporate identity, and ubiquity" (213).[ $\underline{\mathbf{5}}$ ] Reading the letters in The Advocate, I come across a case in point from Yvetta Grim: "Driving home from visiting my family over the holidays... I was in a mood full of despair and reflection (my family is still struggling with my coming out). Somehow I was jolted by a passing black Mitsubishi with Texas plates displaying a pink triangle, rainbow flag, and Ann Richards bumper stickers. In that moment I realized that I wasn't alone. I have this wonderful chosen family, millions strong. I have made it my New Year's resolution to discard my fears and to purchase the same items for my car to help pass this solidarity along."[ $\underline{\mathbf{6}}$ ] As an "out" lesbian participant in the predominantly straight world of bourgeois academic social relations, I can relate to Grim's longing for a solidarity that can be purchased in the passing lane, no time-consuming rest stop coalition building required. At the same time, I see the logic in Case's concern that the ascension of "queer" merchandising and corporate organizing strategies has brought with it the wholesale commodification of lesbian politics, so that however much queer interrogates the "normal," it seems to overlook its own complicity with the "normalizing operations of patriarchy, capital and nation."[ $\underline{7}$ ]

Reading Grim's letter in light of my own collection of glossy magazine subscriptions and in-your-face teeshirts, I am reminded of a character from David Leavitt's novel, The Lost Language of Cranes. Jerene is an African-American lesbian Marxist feminist who amplifies and embodies social "differences" otherwise unexplored in the narrative-specifically race, sex, and class. Through Jerene, lesbian feminism is represented as primarily a matter of what clothes women wear and whether or not they deem it appropriate to shave their legs. As she labors over her never-ending dissertation and haunts the predominantly white dyke bars of lower Manhattan, Jerene wearies of her flannel shirts and mannish attire, the lackluster dress code of the p.c. lesbian-feminist. On a whim, she ventures into the Laura Ashley store to shop for something frilly and forbidden. Picking up more than she initially bargained for, Jerene gets a date with the salesgirl-coincidently, also named Laura-and shortly afterwards discovers her inner femme, the lipstick 
lesbian she was always meant to be. Regrettably, Leavitt's account of Jerene's liberation from lesbianfeminism's downwardly-mobile dogma is lacking in the elements of parody and camp that were so crucial to the dyke style-wars of the 1980s. Also, given Laura Ashley's association with a white, upscale market, Jerene's conversion implies social contradictions that one might reasonably expect a Marxist feminist in the throws of a doctoral dissertation to at least take note of. But Leavitt portrays Jerene as desirous of no more than what Banana Republic offered in its "Chosen Family" ad campaign, an elite consumer base, a bit part in capitalism's romance with difference. Jerene buys in, her customer satisfaction ostensibly indicating a shift in the lesbian styling of political participation. Trash the Marx and the Birkenstocks, strap on Foucault and a stonewashed denim dildo harness from Gay-Mart!

In other arenas of cultural production global capitalism's capacity to satisfy individualized lesbian lusts is more thoughtfully explored. For example, in Rose Troche's recent film, Go Fish--a film heralded in the lesbian press as "a new film for a new generation"-shopping for romance represents a complex strategy for rethinking identity, a strategy with pleasurable and subversive potential.[ $\underline{\boldsymbol{8}}$ ] In this way, the film deploys the genre of romance in order to simultaneously blur and recall historical structures of lesbian subjectivity. Set in Chicago-significantly, the home of the first US department store-Go Fish is about the insertion of the "lesbian" as a romantic consumer and consumer of romance in technoculture. Max, the young protagonist of the film, goes shopping for a girlfriend and discovers Eli, a 70s throwback. In turn, both Max and Eli discover the unpredictable pleasures of queer romance. Describing the film's original contribution to the new queer cinema, Troche claims that it undertakes the "despectacularization... of lesbian lives."[ $\underline{9}$ ] However, to a large extent this "despectacularization" is pure spectacle, represented by Eli's shift from dowdy, lesbianfeminism to queer performativity organized around mobile sexualities and highly individualized pleasureconsuming strategies. The ritualistic montage of images depicting Eli's long-overdue haircut suggests that she is trading in her bland hippie "look" and a long-distance monogamous relationship that has sexually stalled out, for a post-hip-hop "do" and an exciting new sexual currency. However, the question remains, can lesbians "despectacularize" into a queer market sector and still retain the presence and visibility of the body as part of what animates romance, let alone politics? What does 
the already notorious finger nail clipping scene say about the undeniable materiality of the body and the specificity of lesbian sexual practice? What are the romantic pleasures that viewers of Go Fish are invited to consume, even while they are asked to question the ability of technoculture to mobilize political communities and coalitions? Is Go Fish an elegy for lesbian-feminism or an argument for its recuperation?

These questions are currently the focus of academic cultural production as well. In a presentation delivered at last year's MLA, Teresa de Lauretis states that lesbian studies is in a "predicament... caught between an older generation of lesbian scholars whose lives and works and political formation intersected with 70s and 80s feminisms, and the pressing consumer demand for new and more sexy academic performances."[ 10 ] Here, de Lauretis turns to Robyn Wiegman's introduction to The Lesbian Postmodern, an anthology treated as "symptomatic" of current generational shifts in the discourse on sexuality. De Lauretis paraphrases Wiegman, describing the project as an "adventurous... leap into the unknown," a book that will replace an outmoded lesbian-feminist imaginary and displace the commodification of the lesbian that circulates in the mass media and in academia.[ 11 ] At the same time, de Lauretis notes, Wiegman rightly recognizes her own complicity with the contradictory commodification embodied in the book's title.

Notwithstanding these assertions, de Lauretis focuses on lesbian pomo's tendency to speak in the "very lexicon of the feminist theory that I have been practicing for some twenty years...long-familiar terms like unsettle, destabilize, test limits, undermine, heterosexual hegemony and so forth." Same vocabulary, different imaginary. This leads de Lauretis to ask, "what is Pomo about the lesbian without quotation marks, besides her rightly postmodern lack of historical memory?" The answer, it seems, is to be found in this rising generation's repudiation of both femininity and the female body. In its place we now find a semiotic fascination with cyborgs, female-to-male-transsexuals, and Barbie. Lesbian-boomers build their pomo dream houses out of the same old materials they claim to have updated and improved.

De Lauretis's critique echoes, in many respects, recent critiques of "queer theory," a term that she herself coined and has since distanced herself from because of its deployment in contexts that neutralize rather than specify differences. On these grounds, lesbian pomo 
takes issue with queer theory as Wiegman demonstrates, speaking effectively on behalf of those who believe that there is value in retaining the specificity of lesbian existence.[ 12 ] For some, however, the neutralization of bipolarities implicit in the category "lesbian" is precisely what made queer politics, and its academic consort queer theory, viable. Queer's inclusion of multiple differences and parallels that produce discontinuities of sex and gender in socially and racially diverse historical contexts promises stronger coalitions among gay, lesbian, transgender, transsexual, and bisexual communities in their efforts to reform institutionalized heterosexism.

Such coalitions are urgently needed, as was made brutally clear in the case of Brandon Teena, a 21 year old female to male transgender who was multiply raped and murdered by two men in a small town outside Lincoln, Nebraska after the local newspaper reported on his preoperative status. However, as Kathleen Chapman and Michael du Plessis point out, when we turn to Marjorie Garber, a critic whose work is associated with queer theory, we learn that transsexuals and transvestites are more than ever becoming "united around issues like the right to shop-access to dresses and nightgowns in large sizes and helpful, courteous sales personnel"(15-16).[ 13 ] This is a legitimate concern, and I don't mean to dismiss the importance of it or of Garber's work. What I want to do is emphasize that there are actual lives at stake here, lives threatened by institutional structures of oppression that cannot be sufficiently redressed by trolling the racks at Contempo Casuals or by activating credit with Uncommon Clout.

Maybe this is all just a bad case of spring fever, but preparing this paper has convinced me that my place in a feminist line of descent is determined by three, possibly four, market sectors, each one offering a mixed bag of pleasure and risk. Given this precarious position, a position that may be shared by some of the producers and consumers of Feminism Beside Itself, I would like to offer two final observations intended to serve as grist for further thought and discussion.

1) Academic generations are produced, largely although not exclusively, by and within the capital building technologies of academic institutions. Consequently, academic feminism's "generational anxieties" may be productively defined as the effects of institutional restructurings and institutional entanglements with local economies and global capitalist projects. As privileged participants in what Cornel West calls "the academic 
'professional managerial class, '" we are in a position to be particularly attentive to the rise of a lesbian-feminist managerial class whose newly-attained status as a visible "target market" works to displace class difference and camouflage the emergence of a virulent class politics within lesbian movements and communities. Whether we identify as queer, lesbian, lesbian-feminist, or nonheterosexist feminist, now may be the time to reevaluate the ways in which class differences inform academic feminism's manner of talking sex.

2) A rising generation of lesbian scholars identify neither with lesbian-feminism nor queer, believing that the latter retains gay men as its implicit referent while the former has become increasingly elitist, centrist, and removed from the material and political realities of women's lives. While this is not a new concern, it is one that feminism can scarcely afford to put off as congressional threats to women's welfare, housing, and health become enacted in punitive funding cutbacks, and as the moral rhetoric fueling the preservation of traditional "family values" and corporate welfare demonizes women, blacks, queers, the elderly, the sick, and the poor. Katie Hogan, for example, has argued eloquently for the need of academic feminism to recognize that HIV and AIDS is an urgent women's health issue. In trying to write about her sister's death from AIDS in a feminist context, Hogan realized the frightening extent to which an established generation of feminists regard HIV and AIDS as a gay male issue or a non-academic social problem. Additionally, she has realized first-hand "that academic writing connected to women's bodies, health, emotions, and experiences" remains to a large degree suspect (4).[ 14 ]

Hogan's study raises the important question of what can count as feminist theory, a question as central to Elizabeth Grosz's Volatile Bodies as to the performance art of Annie Sprinkle and the instructional safe-sex videos of Fatale. While these works are very different, I take them as collectively indicative of a diverse feminist interventionist discourse that is asserting itself on behalf of bodies at risk of "zeroing out": women's bodies, queer bodies, non-white bodies. Nearly fifteen years have passed since the Barnard Conference opened up a series of difficult and necessary debates on feminism and sexuality; and yet, I wonder, where was the organized feminist response to the firing of former surgeon general Jocelyn Elders as a result of her willingness-her outspoken willingness-to defend safe, nonreproductive sexual practice? From lesbian-feminism to queer, from the Lavender Menace to the Leather Menace, now is the 
time for feminism to take careful account of the emerging discourse on safe sex before another explosion of open conflict-a Latex Menace, perhaps-impedes the formation of necessary social coalitions and fractures alliances with future feminist generations.

\section{NOTES}

1. This is a rephrasing of King's introduction to "The Situation of Lesbianism as Feminism's Magical Sign: Contests For Meaning and the U.S. Women's Movement, 1968-1972," reprinted in King's Theory in It's Feminist Travels: Conversations in U.S. Women's Movements (Bloomington: Indiana University Press, 1994), pp. 124-137.

2. See, for example, the essays collected in Pleasure and Danger: Exploring Female Sexuality, ed. Carole S. Vance, (Boston: Routledge \& Kegan Paul, 1984), and Powers of Desire: The Politics of Sexuality, ed. Ann Snitow, Christine Stansell, and Sharon Thompson (New York: Monthly Review Press, 1983).

3. Sue-Ellen Case, "Toward a Butch-Feminist Retro Future," Purposes: Lesbian Studies, Feminist Studies, and the Limits of Alliance, ed. Dana Heller (Bloomington: Indiana University Press, 1996).

4. Case, "Toward a Butch-Feminist Retro Future," p. 11.

$\underline{\mathbf{5}}$. Lauren Berlant and Elizabeth Freeman, "Queer Nationality." Fear of a Queer Planet: Queer Politics and Social Theory, ed. Michael Warner (Minneapolis: University of Minnesota Press, 1993), pp. 193-229.

6. Yvetta Grim, "Lesbian on Board," The Advocate (March 7, 1995), p. 8.

7. Case, "Toward a Butch-Feminist Retro Future," p. 16.

8. Elizabeth Pincus, "Compliments for Fishing,"

Deneuve: The Lesbian Magazine 4.4 (August 1994), p. 17.

9. Pincus, p. 17. 
10. Teresa de Lauretis, "The Homosexual Imaginary of Feminism," special session, MLA Convention, San Diego, 28 Dec. 1994.

11. De Lauretis, "The Homosexual Imaginary of Feminism."

12. Robyn Wiegman, "Introduction: Mapping the Lesbian Postmodern," The Lesbian Postmodern, ed. Laura Doan (New York: Columbia University Press, 1994), pp. 1-22.

13. Quoted in Kathleen Chapman and Michael du Plessis, "'Don't Call Me Girl': Lesbian Theory, Feminist Theory and Transsexual Identities, " Cross Purposes: Lesbian Studies, Feminist Studies, and the Limits of Alliance. Noting the frequent elision of transgenderism and transsexualism in the work of prominent feminist, lesbian, and queer theorists, Chapman and du Plessis suggest that "'Queer theory' is perhaps a testimony...that the more a theory of sex changes the more it stays the same," p. 17.

14. Katie Hogan, "When Experience and Representation Collide: Lesbians, Feminists, and AIDS," Cross Purposes.

Accueil Surfaces | Table des matières | Recherche Surfaces Home Page | Table of Contents | Search

PUM | Livres | Revues | Publications électroniques | Vente et distribution 